\title{
A PROIBIÇÃO DE DOAÇÃO DE SANGUE POR HOMENS HOMOSSEXUAIS: UMA ANÁLISE SOB AS TEORIAS DO RECONHECIMENTO DE FRASER E HONNETH
}

\author{
Daniel Carvalho Cardinali ${ }^{122}$
}

Recebido em: 23/08/2016

Aprovado em: 20/12/2016

\begin{abstract}
RESUMO
O presente artigo tem por objetivo analisar a proibição de doação de sangue por homens homossexuais a partir das teorias do reconhecimento formuladas por Nancy Fraser e Axel Honneth. Inicialmente, será exposto o quadro normativo brasileiro em torno da vedação, buscando analisar a sua origem histórica como resposta à epidemia de AIDS. Serão abordadas as distintas políticas no tema da possibilidade de doação de sangue por homossexuais adotadas internacionalmente, para se verificar qual delas é mais consonante com o atual estágio de desenvolvimento científico no tema da AIDS e da hemoterapia. Na segunda parte, serão analisadas as teorias de Fraser e Honneth, trabalhando conceitos chaves desenvolvidos por cada autor e as principais diferenças entre os seus pensamentos. Assim, na seção seguinte, será analisada a vedação da doação de sangue a partir das chaves teóricas construídas anteriormente, para se concluir que a mesma representa uma violação ao reconhecimento de homens homossexuais. Finalmente, serão brevemente expostas as estratégicas jurídicas atualmente colocadas em prática no Brasil para questionar a vedação.
\end{abstract}

Palavras-chave: Doação de sangue. Homossexualidade. Teoria do Reconhecimento.

"Razão tem o vírus HIV, que é sábio porque cândido e, com certeza, não está sob as ordens dos moralistas para denunciar quem é e quem não é”.

João Silvério Trevisan (2011, p. 40)

${ }^{122}$ Mestre em Direito Público e Bacharel em Direito pela Universidade do Estado do Rio de Janeiro (UERJ). 


\section{INTRODUÇÃO}

Nas primeiras horas da madrugada do dia 12 de junho de 2016 - mês do orgulho LGBT $^{123}$ - Omar Mateen invadiu a boate LGBT Pulse em Orlando, Flórida. Armado com uma pistola e um rifle semiautomático, Omar abriu fogo contra as centenas de pessoas que estavam no local, matando 49 pessoas e ferindo outras 53, antes de ser morto pela polícia, naquele que viria a se tornar o pior ataque com armas de fogo na história de um país em que tais incidentes são quase rotineiros. Nos dias seguintes, autoridades, profissionais da saúde e ativistas LGBT fizeram apelos pedindo doações de sangue para atender a urgente necessidade das pessoas hospitalizadas, muitas em estado grave. A lei americana impediu, entretanto, que tal doação fosse feita por homens homossexuais, justamente o grupo mais vitimado pela tragédia (STERN, 2016).

A sistemática adotada pelos EUA a partir de dezembro 2015 requer um ano de abstinência sexual para a doação de sangue por homossexuais, independentemente de considerações sobre a prática sexual ter sido ou não protegida; número de parceiros; existência de relacionamento estável; etc. O mesmo rigor não é aplicado para pessoas cujos parceiros sexuais sejam do sexo oposto e lésbicas, que podem doar com muito mais facilidade (MORRISON, 2015).

A regra é a mesma vigente Brasil: a Portaria no 158/2016 do Ministério da Saúde, que define o regulamento técnico dos procedimentos hemoterápicos, prevê: "Art. 64. Considerarse-á inapto temporário por 12 (doze) meses o candidato que tenha sido exposto a qualquer uma das situações abaixo: IV - homens que tiveram relações sexuais com outros homens e/ou as parceiras sexuais destes". Aqui, igualmente ao que ocorre nos EUA, o nível de rigor no escrutínio das práticas sexuais hétero e homossexuais é distinto; os demais incisos que preveem um período de exclusão aplicável a relações sexuais heterossexuais ou entre mulheres estão relacionados à prostituição; parceiros ocasionais, desconhecidos ou portadores de doença transmissível sexualmente; violência sexual; entre outros.

Embora não haja uma previsão expressa que impeça diretamente homens de doarem sangue em razão de sua orientação sexual, a necessidade de abstinência de qualquer prática sexual com outros homens por um longo período gera uma exclusão de facto de homens

\footnotetext{
123 Junho é considerado o "mês do orgulho" ("Pride Month") nos EUA em razão de a Revolta de Stonewall, episódio considerado a "certidão de nascimento" do movimento LGBT americano contemporâneo, ter acontecido no fim deste mês em 1969. As maiores e mais importantes paradas do orgulho LGBT daquele país acontecem durante este período.
} 
homossexuais do direito de doar sangue (AVILA, 2016, p. 47; MORRISON, 2015, p. 2372). A origem desta vedação, conforme será abordado, se relaciona ao início da epidemia de AIDS, que atingiu em seus primeiros anos a população masculina homossexual de maneira muito mais pronunciada.

O objetivo do presente artigo é realizar uma análise desta vedação sob a ótica das teorias do reconhecimento, com base nas teorias de Nancy Fraser e Axel Honneth. Assim, as discussões médicas e sanitárias, embora em certa medida inevitáveis, não serão o objeto principal do presente estudo. $\mathrm{O}$ foco será explorar os significados sociais que revestem esta proibição, i.e., que tipo de imagem pública do homem homossexual esta ajuda a construir e que efeitos ela pode ter na constituição da subjetividade de homens gays ${ }^{124}$, bem como quais consequências a reversão destas proibições poderia trazer sob a ótica de uma política de reconhecimento.

A primeira parte se dedicará a retratar de maneira sucinta as origens históricas desta proibição, com uma análise das respostas dadas ao tema por diferentes países, bem como os avanços no conhecimento científico que as vêm colocando em xeque. A segunda parte abordará os principais aspectos das Teorias de Reconhecimento de Nancy Fraser e Axel Honneth, explorando os conceitos e ideias desenvolvidos por cada autor e as diferenças entre cada uma das teorias, com vistas a construir as chaves teóricas necessárias para a análise do objeto de interesse do presente artigo. A terceira parte se dedicará a explorar os significados que a vedação da doação de sangue por homens gays assume com base nos referenciais teóricos explorados na seção anterior. Finalmente, a parte final se dedicará a mencionar brevemente as estratégicas jurídicas atualmente colocadas em prática no Brasil para questionar a vedação.

\section{A REGULAÇÃO DA VEDAÇÃO DE DOAÇÃO DE SANGUE POR HOMOSSEXUAIS: DO “CÂNCER GAY” AOS COMPORTAMENTOS DE RISCO}

O surgimento da AIDS nos anos 1980 foi marcado por uma aura de "confusão e incerteza”, em que um número crescente de homens, até então saudáveis, passaram a inundar os hospitais de Nova Iorque, São Francisco e outros centros urbanos americanos com doenças graves, como sarcoma de kaposi ${ }^{125}$, vindo a óbito antes que os médicos pudessem entender o

\footnotetext{
${ }^{124}$ Em que pese alguma discussão sobre os termos, para fins do presente artigo "homens homossexuais" e "homens gays" serão utilizados de forma intercambiável.

${ }^{125}$ Espécie até então rara de câncer de pele característica pelas manchas arroxeadas que deixa no corpo.
} 
que estava acontecendo. A nova e misteriosa doença, que parecia então restrita a homens homossexuais, foi num primeiro momento provisoriamente nomeada de GRID - Gay-Related Immune Deficiency (imunodeficiência relacionada à homossexualidade), vindo a receber o nome AIDS (síndrome da imunodeficiência adquirida, na sigla em inglês) somente em 1982 (MCADAM \& PARKER, 2014; MORRISON, 2015).

A partir do primeiro caso de contaminação pelo vírus HIV em decorrência de transfusão de sangue infectado, em 1982, instaurou-se um pânico nos EUA acerca dos suprimentos dos bancos nacionais de sangue. As limitações existentes naquele momento, em que origem e métodos de transmissão da doença ainda eram objeto de debate, bem como a impossibilidade de testar o sangue doado para verificar a presença do vírus, estimularam a Food and Drug Administration - FDA, entidade governamental responsável por normas de saúde pública, a proibir a doação de sangue por homens que houvessem feito sexo com outros homens. Assim, a partir de 1983, todos os homens que houvessem tido qualquer contato sexual com outro homem desde 1977 ficariam vedados de doar sangue por tempo indeterminado, no que ficou conhecido como o "gay blood ban" ("proibição do sangue gay"; MORRISON, 2015). No Brasil, a mesma exclusão definitiva de homens homossexuais começou a ser implementada a partir de 1985 e perdurou até 2002, quanto foi revista para a política atual (AVILA, 2016, pp. 28-29).

Neste período, a discussão em torno da AIDS centra-se na categoria de "grupos de risco", que traduzia certa noção essencialista do risco da doença em relação a sujeitos determinados. Um dos principais desses "grupos de risco" - talvez o principal - é formado pelos HSHs ("homens que fazem sexo com outros homens") ${ }^{126}$. Trata-se de uma categoria formulada pelo discurso médico e empregada nas discussões e protocolos referentes ao HIV/AIDS e outras DSTs. A sigla foi estrategicamente engendrada para fazer referência direta às práticas sexuais, evitando a discussão acerca do possível descolamento entre práticas e identidades (e.g. homens que se identificam com a heterossexualidade, mas esporadicamente se relacionam com outros homens), principalmente num momento histórico em que a identificação como homossexual poderia ser ainda mais estigmatizante, afugentando alguns homens dos programas de prevenção. A sigla, por outro lado, é objeto de crítica por ativistas, por ser invisibilizadora de identidades e sujeitos políticos (FACCHINI \& FRANÇA, 2009, p. 64). Debates a parte, é evidente que parte substancial dos HSHs é formada por homens

${ }^{126}$ Tradução da sigla MSM (“men who have sex with men”), utilizada no debate estadunidense. 
homossexuais, inclusive na medida em que os atos sexuais temporariamente vedados são em alguma medida constitutivos da própria identidade destes sujeitos.

A epidemia de AIDS produziu efeitos complexos sobre a formação da identidade e visibilidade homossexuais. Por um lado, a doença atingiu mais fortemente, além deste grupo, usuários de drogas injetáveis e prostitutas, sujeitos socialmente estigmatizados, o que produziu um discurso moralizante de culpabilização da própria vítima (PELÚCIO \& MISKOLCI, 2009), que hora assumia cores pretensamente científicas ("câncer gay”), ora atualizava um discurso religioso ancestral ("castigo divino"). Neste sentido, o a abordagem midiática da "doença dos homossexuais" americana, sensacionalista e pejorativa, contaminou o debate público brasileiro em torno do tema (AVILA, 2016). De certa maneira, a epidemia da AIDS forneceu uma oportunidade de contra-ataque para o discurso conservador, após a "revolução sexual" e a despatologização da homossexualidade pela Associação Psiquiátrica Americana em 1974 e, no Brasil, pelo INAMPS em 1985, em prol das formas tradicionais e monogâmicas de família (TREVISAN, 2011, pp. 437 et seq). O "pânico moral" que caracterizou o debate sobre a doença na época foi responsável pela criação de uma duradoura e renitente correlação entre a AIDS e a homossexualidade.

Neste contexto surge a bioidentidade do "aidético", termo que ganharia forte conotação pejorativa (PELÚCIO \& MISKOLCI, 2009). Isto porque, nos primeiros anos, como vimos, a AIDS parecia reduzida a uma "doença de viado", e o medo de contrair HIV/AIDS vinha ligado ao medo de ser arrancado do armário ou de acharem que se era sem ser ${ }^{127}$. Neste sentido, a figura do homem extremamente magro com o corpo sarapintado de manchas roxas não chocava apenas pela doença em si, mas por transformar a homossexualidade - real ou suposta - de estigma desacreditável em estigma desacreditado ${ }^{128}$.

Em sentido oposto, entretanto, a epidemia de AIDS teve também efeitos importantes sobre a construção da visibilidade homossexual: a doença mudou drasticamente as falas sobre sexualidade e sexo que, se por um lado se davam por um viés medicalizante e higienista, por

\footnotetext{
${ }^{127}$ Neste sentido, Didier Eribon: “A Aids, com frequência, significou o coming out forçado daqueles que até aqui tinham preferido calar a homossexualidade, recebendo, como consequência, a hostilidade dos vizinhos, dos colegas, da família. Para muitas pessoas atingidas, não era apenas a soropositividade ou a Aids que eram difíceis de 'dizer', mas também, é claro, a homossexualidade, embora a vergonha ser homossexual fosse reforçada pela vergonha de ser doente e doente de uma doença que reforçava a vergonha de ser homossexual" (ERIBON, 2008, p. 58).

${ }^{128}$ A distinção foi formulada por Erving Goffman para retratar a diferença entre os estigmas imediatamente identificáveis (p. ex. a cor da pele ou a condição de mulher ou de deficiente físico), que seriam as identidades desacreditadas; e aqueles não imediatamente perceptíveis ou ocultáveis (p. ex. a orientação sexual), que seriam identidades desacreditáveis (GOFFMAN, 1988, p. 14).
} 
outro retiraram as práticas homossexuais da clandestinidade e do âmbito do não dito, catapultando-as para o centro do debate público (FACCHINI \& FRANÇA, 2009, pp. 133-135; TREVISAN, 2011, p. 370). Outro paradoxo diz respeito ao próprio enquadramento enquanto "grupo de risco" que tanto opera no reforço de estigmas, quanto legitima a formulação de políticas públicas, estratégias e aportes orçamentários específicos para a população homossexual (SANTOS, 2007).

Fato é que, com o passar dos anos, o conhecimento científico em torno do tema do HIV/AIDS aumentou sensivelmente, de modo que as formas de contágio hoje são objeto de consenso científico e o diagnóstico da doença não é mais a sentença de morte de outrora, e muitas pessoas soropositivas mantém vidas ativas e produtivas. Parte importante destes avanços se deu com o desenvolvimento ao longo do tempo de novas e cada vez mais eficientes técnicas de testagem do sangue (MACADAM \& PARKER, 2014), que passaram a ser incorporadas às rotinas de controle de qualidade do sangue doado ${ }^{129}$. Com efeito, o desenvolvimento científico tornou a vedação da doação de sangue por homossexuais cada vez menos popular entre a comunidade médica e população em geral (MORRISON, 2015; AVILA, 2016).

Nesta toada, deve ser levado em consideração que as políticas de doação de sangue, incluindo a previsão de restrições e impedimentos, devem ser formuladas com vistas ao atendimento de dois objetivos muitas vezes conflitantes: manter um suprimento adequado, o que implica permitir o máximo possível de pessoas a doarem sangue; e garantir a qualidade do sangue doado, impedindo a doação de pessoas cujo sangue possa representar risco para o receptor (MORRISON, 2015). Indaga-se, assim, qual a melhor resposta no tocante à possibilidade de doação de sangue por HSHs para o atendimento simultâneo dos dois objetivos.

Atualmente, a resposta dada pelos diversos países quanto à possibilidade de HSH doarem sangue envolve a adoção de uma das três políticas seguintes: (a) exclusão definitiva; (b) exclusão por um período de tempo determinado e (c) ausência de período de exclusão específico para HSH.

A primeira política é adotada atualmente por países como Alemanha, China, Índia, Filipinas, Suíça, Turquia e Venezuela, enquanto a segunda política é adotada, entre outros, por

\footnotetext{
${ }^{129}$ Neste sentido, a Portaria ${ }^{\circ}$ 158/2016 prevê: “Art. 129. O serviço de hemoterapia realizará testes para infecções transmissíveis pelo sangue, a fim de reduzir riscos de transmissão de doenças e em prol da qualidade do sangue doado.

Art. 130. É obrigatória a realização de exames laboratoriais de alta sensibilidade a cada doação, para detecção de marcadores para as seguintes infecções transmissíveis pelo sangue, cumprindo-se ainda, os algoritmos descritos no Anexo V para cada marcador: I - sífilis; II - doença de Chagas; III - hepatite B; IV - hepatite C; V - AIDS; e VI - HTLV I/II".
} 
Austrália, Canadá, França, Reino Unido, Japão, e, atualmente, os EUA. A maioria dos países desse segundo grupo prevê a exclusão da doação pelo período de um ano, com exceção do Canadá, em que o prazo é de cinco anos, e o Japão, em que o prazo é de seis meses, o mesmo prazo para um novo parceiro heterossexual (MACADAM \& PARKER, 2014). Finalmente, África do Sul, Argentina, Colômbia, Chile, Espanha, Itália, México e Portugal integram o terceiro grupo, em que a exclusão é feita com base na ideia de "comportamentos de risco" e não de "grupo de risco". Embora a ideia do que seja comportamento de risco varie largamente de país para país, podendo envolver considerações sobre o uso de preservativos, número de parceiros sexuais, tempo de relacionamento com o parceiro sexual, etc., as políticas destes países se caracterizam por aplicar as mesmas regras para todos os doadores, independentemente de as práticas sexuais serem hetero ou homossexuais (MORRISON, 2015).

Conforme já foi narrado, o Brasil está enquadrado no segundo grupo de países, por força do supracitado art. 64, IV da Portaria n 158/2016 do Ministério da Saúde. Apesar disso, o diploma normativo contém um preceito expresso vedando a discriminação em razão da orientação sexual dos doadores:

\begin{abstract}
Art. $2^{\circ} \S 3^{\circ}$ Os serviços de hemoterapia promoverão a melhoria da atenção e acolhimento aos candidatos à doação, realizando a triagem clínica com vistas à segurança do receptor, porém com isenção de manifestações de juízo de valor, preconceito e discriminação por orientação sexual, identidade de gênero, hábitos de vida, atividade profissional, condição socioeconômica, cor ou etnia, dentre outras, sem prejuízo à segurança do receptor.
\end{abstract}

A incongruência é patente; se por um lado a portaria garante um acolhimento isento de discriminação em razão da orientação sexual dos doadores, por outro exclui deliberadamente homens gays que tenham uma vida sexual minimamente ativa, mesmo que em relações estáveis e com uso de preservativos. Com efeito, a atual política, em última instância, impede a doação sangue por estes sujeitos não em razão de determinados comportamentos de risco, mas em razão de um "traço inerente que existe independentemente de risco" (MORRISON, 2015, p. 2381).

Por outro lado, não deve impressionar que a Portaria não fale em "grupo de risco", o que poderia denotar uma superação desta concepção científica. Como visto, a pretensa descrição da conduta de sendo homem, manter relações sexuais com outro homem, descreve não um efetivo "comportamento de risco", mas sim um sujeito específico que seria mais propenso a contrair o vírus HIV. Neste sentido, “o que há, sob uma tentativa mal disfarçada de definição de conduta, é a fixação de um grupo de pessoas com sexualidade historicamente desviante e vítima de preconceito" (AVILA, 2016, p. 45). 
Ademais, o conhecimento científico avançou muito desde os anos 1980, sendo consenso que a orientação sexual não tem qualquer relação com a transmissão de HIV (LARKIN, 2011). Significa dizer, uma pessoa não contrai HIV/AIDS porque é gay ou participou de um ato homossexual, e sim porque se envolveu em alguma situação de risco, como sexo sem proteção; o foco, portanto, deve migrar para a consideração destes comportamentos, independentemente de a prática sexual envolver parceiros de mesmo ou distinto sexo (MACADAM \& PARKER, 2014).

\section{AS TEORIAS DO RECONHECIMENTO DE NANCY FRASER E AXEL HONNETH}

A ideia filosófica de reconhecimento remonta a Hegel, especialmente à célebre imagem do Senhor e do Escravo que o autor desenvolve em sua Fenomenologia do Espírito para retratar a formação intersubjetiva e dialógica dos sujeitos, em oposição ao sujeito kantiano eminentemente individual, racional e a-histórico (ASSY \& FERES JÚNIOR, 2009). O tema, entretanto, ganhou fôlego a partir da emergência nos anos 1960 dos chamados "novos movimentos sociais", como o movimento de liberação gay e a $2^{\mathrm{a}}$ onda do feminismo, cujas demandas identitárias e culturais se diferenciavam das demandas operárias tradicionais (SARMENTO, 2016).

Em que pese a questão do reconhecimento ter sido objeto de consideração de outros autores, com destaque para Charles Taylor, creditado por tê-la reintroduzido no debate contemporâneo (ASSY \& FERES JÚNIOR, 2009), o presente artigo trabalhará com as chaves teóricas oriundas do pensamento de Nancy Fraser e Axel Honneth. Estes teóricos foram escolhidos pela contribuição que suas obras podem trazer para a reflexão sobre o objeto do presente estudo - a vedação da doação de sangue por homossexuais masculinos -, bem como pelo fato de terem travado uma célebre discussão acadêmica ${ }^{130}$, que evidenciou os pontos de convergência e divergência entre suas teorias.

Cabe destacar, antes de qualquer coisa, que a escolha por falar em teorias do reconhecimento no plural é deliberada, na medida em que não apenas as teorias de cada autor apresentam viscerais diferenças entre si, conforme será explorado, mas cada um deles emprega a noção de reconhecimento em um dado sentido e com uma determinada abrangência; isto é, o

\footnotetext{
${ }^{130}$ Refiro-me aqui evidentemente a FRASER \& HONNETH, 2004.
} 
conceito e o alcance do termo reconhecimento são distintos para Fraser e Honneth. Com efeito, em alguma medida, a disputa entre os dois tem uma natureza terminológica sobre o uso do termo (FRASER, 2003b, p. 199). Dito isto, será realizada uma análise, sem qualquer pretensão de exaustividade, dos principais pontos das teorias de cada um dos autores; eventuais divergências serão mais exploradas na medida em que interessem ao objeto do presente artigo na seção seguinte.

Nancy Fraser é uma autora estadunidense ligada à teoria crítica e à teoria feminista, cujas ideias criativas e influentes passaram por diversas transformações ao longo do tempo. Embora tenha sido incorporada ao repertório acadêmico brasileiro como uma autora profundamente ligada à teoria do reconhecimento, Fraser é muito crítica de um processo de prevalência que as políticas de reconhecimento e as questões culturais estariam assumindo no mundo pós-socialista, em detrimento das políticas de redistribuição, apesar do aprofundamento da desigualdade econômica provocado pela globalização e o neoliberalismo (FRASER, 2004).

Neste sentido, a autora procura desenvolver uma concepção integrada de justiça, capaz de enfrentar os diferentes tipos de igualdades. Assim, a autora parte de um "dualismo perspectivo", segundo o qual as injustiças podem ter causas econômicas, requerendo remédios baseados em políticas de redistribuição; ou causas culturais, que demandam para o seu enfrentamento políticas de reconhecimento ${ }^{131}{ }^{132}$. Mais do que isso, as duas concepções partem do pressuposto de que as coletividades atingidas pela injustiça têm naturezas diferentes: enquanto os grupos que sofrem com problemas de redistribuição assumiriam a natureza de classes sociais típicas da teoria marxista, as coletividades que sofrem com problemas de reconhecimento se assemelhariam mais aos grupos de status weberianos (FRASER, 2010).

Segundo Fraser, as injustiças de reconhecimento são tradicionalmente concebidas como "distorções de identidade", com base na noção hegeliana de que a identidade se constrói intersubjetivamente (FRASER, 2004, pp. 604 et seq). A autora, entretanto, busca desenvolver

\footnotetext{
131 “Cada dimensão está associada a uma dimensão analiticamente distinta de injustiça. Para a dimensão de reconhecimento [...] a injustiça associada é o não-reconhecimento, no qual padrões arraigados de valor cultural negam a alguns atores a importância necessária para participar integralmente da vida social. Para a dimensão distributiva, por sua vez, a injustiça correspondente à má distribuição, na qual as estruturas econômicas, tais como regimes de propriedade e mercados de trabalho, privam alguns atores dos recursos necessários. Cada dimensão, por fim, corresponde a uma forma analiticamente distinta de subordinação. A dimensão do reconhecimento corresponde, como já vimos, à subordinação de status enraizada em padrões institucionalizados de valor cultural. A dimensão distributiva, por sua vez, corresponde à subordinação econômica, enraizada em características estruturais do sistema econômico" (FRASER, 2004. pp. 616-617)

132 Por outro lado, deve ser destacado que a autora entende ser possível a existência de outras formas de injustiça, i..e, outras formas de ordenação social produtoras de outras formas de subordinação, destacando que talvez a dimensão política poderia ser considerada uma candidata a este tertium genus (FRASER, 2003a, p. 68).
} 
um modelo alternativo, que enxerga o não-reconhecimento como um problema de "status social" (FRASER, 2004, pp. 610 et seq). De acordo com este modelo, deve-se analisar os padrões institucionalizados de valor cultural pelos seus efeitos sobre a posição relativa dos atores sociais; isto é, quando estes padrões encararem os atores como iguais, conferindo-os o mesmo valor, poderia se falar em igualdade e reconhecimento recíproco, ao passo que padrões diferentes, que encaram os atores como inferiores ou superiores, produziriam exclusão e desigualdade, por meio de uma subordinação de status e não-reconhecimento (FRASER, 2003a, pp. 29-30). Neste sentido, o objetivo das políticas de reconhecimento seria, assim, a construção de um mundo tolerante e respeitoso com a diferença, no qual a assimilação a padrões culturais hegemônicos não fosse um preço necessário a ser pago pelas minorias para o gozo de seus direitos.

Apesar da elegância e didatismo dessa bipartição teórica, a autora advoga que as políticas de reconhecimento e redistribuição não são necessariamente excludentes, e que as injustiças concretas podem assumir ambas as faces simultaneamente, que ela chama de “coletividades bivalentes", como seria o caso da injustiça em razão do gênero ou da raça. Assim, embora algumas injustiças se aproximem mais de um ou outro extremo, as injustiças concretas poderiam ser arranjadas ao longo de um gradiente entre os dois polos da redistribuição e do reconhecimento, requerendo, para seu enfrentamento, remédios de ambos os tipos (FRASER, 2010, pp. 171-178) $)^{133}$.

Quanto aos remédios de reconhecimento e de redistribuição que visam o enfrentamento das respectivas injustiças, a autora entende que podem se basear em estratégias afirmativas e transformativas. Os remédios baseados em estratégias afirmativas buscam corrigir as injustiças decorrentes dos arranjos sociais sem mexer nas estruturas sociais que os produzem, enquanto as estratégias transformativas pretendem justamente a transformação profunda das estruturas sociais produtoras da injustiça. Assim, por exemplo, a extensão do direito de casamento a casais do mesmo sexo é uma estratégia afirmativa, ao passo que estratégias que questionam a própria regulação estatal da vida privada são marcadamente transformativas. A autora entende que as políticas transformativas são preferíveis às meramente afirmativas, embora sejam mais difíceis de implementar na prática. Neste sentido, Fraser defende a via media da "reforma não-

\footnotetext{
133 A autora defende, portanto, que a sua noção de "dualismo perspectivo" entende o reconhecimento e a redistribuição como "analiticamente distintos". Do ponto de vista concreto, entretanto, os dois não ocupam esferas sociais separadas, pelo contrário, eles "se interpenetram para produzir padrões complexos de subordinação" ("distribution and recognition do not occupy separate spheres. Rather, they interpenetrate, to produce complex patterns of subordination”; FRASER, 2003b, p. 217.
} 
reformista", que seriam medidas aparentemente afirmativas, mas que cumulativamente possuem o potencial de gerar, a longo prazo, efeitos transformativos (FRASER, 2003a, pp. 74$80)$.

Por fim, uma noção central no pensamento de Fraser é a de paridade de participação, que exige todos os membros da sociedade possam interagir entre si como parceiros livres e iguais, requerendo para isso a distribuição de bens materiais suficientes (condição objetiva) e padrões culturais de igual respeito (condição intersubjetiva). É justamente com base nessa ideia normativa que a autora vai justificar deontologicamente as políticas de redistribuição e reconhecimento (FRASER, 2003a e 2003b).

Já Axel Honneth é um autor alemão ligado à escola de Frankfurt e à teoria crítica, que desenvolveu em sua obra Luta por Reconhecimento uma influente teoria a partir da influência decisiva dos trabalhados do jovem Hegel, coordenados com a psicologia social de George Mead. O autor emprega uma noção bastante ampla de reconhecimento, descolada dos "novos movimentos sociais", segundo a qual os conflitos e demandas sociais de vários tipos - inclusive redistributivos - são formulados essencialmente como buscas por reconhecimento, em distintas esferas $^{134}$. Neste sentido, o autor se desliga da cisão promovida pela teoria de Nancy Fraser entre reconhecimento e redistribuição.

Para o autor, o reconhecimento pode ser desdobrado em três esferas distintas: amor, direito e solidariedade. $\mathrm{O}$ reconhecimento em cada uma destas esferas produz uma espécie de autorrelação prática para os sujeitos: autoconfiança, autorrespeito e autoestima; ao passo que o seu "não-reconhecimento" gera uma forma distinta de desrespeito: violação, privação de direitos e degradação, que exerce um impacto negativo na forma pela qual os sujeitos se enxergam ("autoimagem").

A primeira esfera, do amor, envolve as relações primárias do sujeito com os pais, família, amigos, etc. (HONNETH, 2003a, p. 159). O reconhecimento nesta esfera está relacionado ao atendimento de suas necessidades afetivas, principalmente na relação entre mãe e bebê $\hat{e}^{135}$, sendo um pressuposto para o desenvolvimento da autoconfiança individual. Para o

\footnotetext{
${ }^{134}$ Segundo o autor, "a resistência a uma ordem social estabelecida é sempre motivada pela experiência moral de em alguma forma não receber o que se entende por reconhecimento justificado" ("resistance to an established social order is always driven by the moral experience of in some respect not receiving what is taken to be justified recognition"; HONNETH, 2003b, p. 160).

${ }^{135}$ Com efeito, a teoria de Honneth neste ponto vale-se largamente dos estudos do psicanalista Donald Winnicott acerca das distintas fases pelas quais passa a relação entre o bebê e a mãe, que vão desde uma simbiose inicial até uma crescente consciência do bebê de sua própria existência independente (HONNETH, 2003a, p. 163).
} 
autor, o desrespeito nesta esfera está ligado à violação que envolve situações de agressão física, tortura e estupro (HONNETH, 2003a, pp. 214-215).

Já a segunda esfera, do direito, a partir do advento das sociedades pós-tradicionais, nas quais o estatuto jurídico independe do pertencimento à certa classe social ou estamento, exprime a concessão de direitos universalizáveis que decorrem do reconhecimento dos indivíduos como sujeitos dotados de autonomia moral (HONNETH, 2003a, pp. 180-182), a partir de sua imputabilidade moral comum (“outro generalizado"). Segundo o autor, as novas demandas por direitos podem ser explicadas por um processo de extensão das propriedades universais de uma pessoa dotada de autonomia moral (HONNETH, 2003a, pp. 187-189). Esta extensão pode ser objetiva, quando novos direitos são incluídos como requisitos de imputabilidade moral (ex. direito sociais) ou subjetiva, quando direitos já existentes são expandidos para novos sujeitos sociais (ex. universalização do sufrágio; HONNETH, 2003a, pp. 193-194). Para o autor, ver-se reconhecido na ordem jurídica produz um senso de autorrespeito nos sujeitos ${ }^{136}$, ao passo que a privação ou a exclusão de direitos faz com que os sujeitos passem a se enxergar como menos merecedores de respeito social (HONNETH, 2003a, pp. 216-217).

Finalmente, a terceira esfera, da solidariedade, está ligada à estima social ou autoconfiança ética que advém do reconhecimento do sujeito não como um sujeito abstrato de direito, e sim em suas propriedades e capacidades concretas. Trata-se da esfera da reputação e prestígio social, que nas sociedades modernas deixou de estar ligada ao status ("honra”), para estar conectada as realizações, escolhas culturais e estilo de vida do indivíduo de acordo com determinados padrões culturais, por meio dos quais o sujeito se sente valioso e útil para o empreendimento comum (HONNETH, 2003a, pp. 198-et seq). Dentro da sociedade burguesa capitalista, cresce em importância nesta seara o "princípio do sucesso" e a lógica meritocrática. O desrespeito nesta esfera, segundo o autor, está ligado à degradação, pela qual a desvalorização social do indivíduo impacta negativamente sua autoestima. Tal situação deriva de padrões culturais de autorrealização que desvalorizam a forma como determinados sujeitos conduzem suas vidas (HONNETH, 2003a, pp. 217-218).

Para o autor, o processo de individuação está ligado à ideia de reconhecimento progressivo nestas três esferas de reconhecimento, sendo marcada por sucessivas lutas

\footnotetext{
${ }^{136}$ Neste sentido, segundo o autor, o reconhecimento de direitos subjetivos como pretensões voltadas aos demais membros da coletividade tem um ganho em si mesmo, que independe da mera satisfação das necessidades individuais. Assim, em uma comunidade hipotética em que houvesse alta beneficência e consideração recíprocas, mas não direitos individuais, ainda assim os sujeitos não possuiriam a chance de constituir um autorrespeito (HONNETH, 2003a, pp. 195-196).
} 
intersubjetivas do Eu em face do Outro. Para o autor, "a reprodução da vida social se efetua sob um imperativo de um reconhecimento reciproco", na qual o parceiro de interação possui uma perspectiva normativa de ser reconhecido (HONNETH, 2003a, p. 155). Por este motivo, as experiências de desrespeito são o gatilho para a formulação de reivindicações sociais de reconhecimento ${ }^{137}$.

Neste sentido, "são as lutas moralmente motivadas de grupos sociais, sua tentativa coletiva de estabelecer institucional e culturalmente formas ampliadas de reconhecimento recíproco" que provocam as mudanças sociais (HONNETH, 2003a, p. 156), dentro de uma perspectiva de desrespeitos compartilhados e resistências coletivas, que compõe a gramática de reinvindicação dos movimentos sociais (HONNETH, 2003a, pp. 257-258).

\section{A VEDAÇÃO DA DOAÇÃO DE SANGUE POR HOMENS HOMOSSEXUAIS E SEUS SIGNIFICADOS}

$\mathrm{O}$ art. 30 da Portaria $n^{\circ}$ 158/2016 estabelece que "a doação de sangue deve ser voluntária, anônima e altruísta, não devendo o doador, de forma direta ou indireta, receber qualquer remuneração ou benefício em virtude da sua realização”. Enquanto um ato altruísta e desinteressado, a doação de sangue é motivada primordialmente pelo desejo abnegado de ajudar o próximo, por meio da contribuição para com o estoque de sangue e, portanto, com a saúde pública. Neste sentido, está longe de ser uma atividade banal, podendo ser entendido como uma "obrigação moral séria" ou pelo menos uma contribuição útil com o "bem maior" (MORRISON, 2015, p. 2387). Não obstante, esta possibilidade de contribuição social é interditada a homossexuais gays em virtude de restrições baseadas em concepções científicas ultrapassadas e padrões de valorização culturais discriminatórios e estigmatizantes. Mais do que isso, esta contribuição solidária só lhes é permitida em desfavor de si próprios, caso "abram mão" de exercer sua sexualidade pelo período de doze meses. A situação se torna mais dramática se pensarmos que alguns destes homens gays, cuja possibilidade de agirem para salvar vidas está sendo negada, possuem tipos sanguíneos mais raros para a doação.

\footnotetext{
${ }^{137}$ Segundo o autor, "as reações negativas que acompanham no plano psíquico a experiência de desrespeito podem representar de maneira exata a base motivacional afetiva na qual está ancorada a luta por reconhecimento" (HONNETH, 2003a, pp. 219-220).
} 
Com efeito, a vedação da doação por homens homossexuais toma a qualificação como HSH como uma ameaça per se, independentemente de comportamento de risco, o que "efetivamente perpetua estereótipos negativos e estigmas relacionados a homens gays e bissexuais ao basear as normas sobre doação em estereótipos, e não ciência" (MORRISON, 2015 , p. 2391 $)^{138}$. Isto porque homens homossexuais são entendidos como intrinsecamente perigosos em razão meramente de sua própria homossexualidade, o que reforça o estigma de que homossexuais são degenerados e promíscuos ou, pior, concepções patologizantes segundo as quais a mera homossexualidade aumenta o risco de infecção pelo vírus HIV ${ }^{139}$. Ademais, a vedação ajuda a criar uma falsa "aura de segurança" entre heterossexuais (LARKIN, 2011).

Pelúcio e Miskolci destacam que o sangue tradicionalmente é uma substância impregnada de significados simbólicos, tendo sido usado para a hierarquização de seres humanos (p. ex. eugenia). A epidemia de AIDS e a normativa sobre a doação de sangue criaram uma imagem de um sangue "sujo", ligado não apenas à contaminação viral, mas à perversão sexual que ele carrega, devendo ser separado do sangue "puro" das demais pessoas (2009, p. $133)$.

Ademais, merece destaque a incongruência de que atualmente o casamento homossexual seja uma realidade jurídica e social, i.e., se reconheça a possibilidade de relacionamentos estáveis, duradouros e monogâmicos entre homens homossexuais, mas que não se permita a doação de sangue com base em ideias antiquadas sobre o comportamento de homens gays (MORRISON, 2015).

Passando à análise da problemática sob as lentes dos referenciais teóricos desenvolvidos na seção anterior, Fraser entende que, ao contrário do que ocorre com a raça e o gênero, a injustiça em razão da orientação sexual seria arquetípica de um problema de reconhecimento, estando localizada próxima deste polo do gradiente. Assim, a injustiça sofrida por homens homossexuais seria decorrente de "padrões institucionalizados de valor cultural que constroem a heterossexualidade como natural e normativa e a homossexualidade como perversa e desprezível" (FRASER, 2003a, p. 18) ${ }^{140}$. Segundo a autora, como visto, o não-reconhecimento

\footnotetext{
138 "effectively perpetuates negative stereotypes and stigmas attached to gay and bissexual men by basing donor guidelines on stereotypes, not science".

${ }^{139}$ Neste sentido. "a mensagem transmitida é a de que, sob o olhar do outro, a própria orientação sexual dos homens homossexuais é em si um risco, exigindo medidas sanitárias protetivas. A medida contém a ideia de que o sangue de homens gays, independentemente de praticarem sexo de forma segura, é sempre visto como fonte emergente de contaminação. Alimenta-se, assim, a estigmatização, a opressão, o sofrimento e os abalos à construção da autoestima e da identidade pessoal. (AVILA, 2016, p. 54)

140 "institutionalized patterns of cultural value construct heterosexuality as natural and normative, homosexuality as perverse and despised". Apesar disso, a autora reconhece que problemas de redistribuição podem derivar destes
} 
é baseado não no modelo de identidade, mas no modelo de status, cujo foco reside na análise das instituições sociais. Neste sentido, o não-reconhecimento ocorre quando instituições desenvolvem políticas manifestas e públicas baseadas em normas e padrões culturais que impedem alguém de participar como um membro pleno da sociedade, i.e., que negam a sua paridade de participação.

Parece evidente que a vedação desarrazoada à doação de sangue por homens homossexuais fere a paridade de participação na sua condição intersubjetiva, ao tratá-los como parceiros sociais inferiores e menos valiosos com base em padrões culturais assimétricos e estigmatizantes. Neste sentido, a exclusão da possibilidade de doação de sangue por HSHs "transmite uma mensagem estigmatizante avessa à ênfase de que a comunidade LGBT é uma parte integralmente aceita da sociedade" (MACADAM \& PARKER, 2014, p. 33) ${ }^{141}$.

Dentro da tipologia desenvolvida por Fraser de remédios transformativos e afirmativos, parece claro que a reversão da proibição de doação de sangue por HSHs gera um efeito meramente afirmativo sobre o reconhecimento de homens gays. Por outro lado, dada a relevância dos aspectos simbólicos ligados à doação de sangue e ao estigma da AIDS em relação ao grupo, é possível advogar que a medida poderia ser em algum nível entendido como uma "reforma não-reformista". Para a autora, este tipo de remédio "modifica mais do que os aspectos institucionais específicos que visam explicitamente atingir, mas também alteram o terreno sobre o qual lutas futuras vão ser conduzidas" (FRASER, 2003a, p. 79) ${ }^{142}$. Neste sentido, sendo um dos últimos resquícios de tratamento formalmente desigual no ordenamento jurídico brasileiro em razão da orientação sexual, a reversão pode desencadear efeitos profundos na luta pela igualdade de direitos, por meio da produção de um ordenamento jurídico radicalmente igualitário no tratamento das pessoas independentemente de sua sexualidade.

Igualmente, é possível encarar o problema com base na teoria de Honneth. Neste sentido, argumenta-se que a vedação da doação de sangue por HSHs produz um desrespeito ao reconhecimento de homossexuais masculinos. Segundo o autor, "a injustiça social é experimentada no momento em que não é mais possível se entender racionalmente porque uma

padrões culturais assimétricos. Assim, por exemplo, uma pessoa pode ser demitida ou ser impedida de gozar de um benefício previdenciário em razão de sua orientação sexual. Neste sentido, injustiças por reconhecimento podem, concretamente, necessitar de alguma política de redistribuição, de tal forma que, do ponto de vista prático todos os tipos de subordinação podem ser entendidos como bidimensionais (FRASER, 2003a, pp. 24-25).

141 "the exclusion of MSMs conveys 'a marginalizing message at odds with the emphasis on the [LGBT] community being a fully accepted part of society"".

142 "When successful, nonreformist reforms change more than the specific institutional features they explicitly target. In addition, they alter the terrain upon which later struggles will be waged". 
regra institucional deveria contar com a concordância de acordo com razões geralmente aceitas" $\left(\right.$ HONNETH, 2003b, p. 130) ${ }^{143}$. Como visto, o desenvolvimento científico colocou em xeque as razões que outrora pareciam razoáveis para defender a vedação à doação de sangue, tornando esta regra institucional crescentemente menos aceita e representada como um problema de reconhecimento pela comunidade homossexual.

Entendida como um desrespeito ao reconhecimento de homens homossexuais, perquirese, agora, qual das três esferas do reconhecimento da teoria formulada por Honneth seria agredida pela medida. Fraser apresenta uma visão bastante crítica quanto à possibilidade de demandas por reconhecimento serem categorizadas definitivamente em uma das três categorias propostas por Honneth, diante de sua complexidade concreta (FRASER, 2003b). O autor, por outro lado, responde que esferas institucionais, como a escola ou a família, podem estar relacionadas a mais de uma esfera de reconhecimento (HONNETH, 2003c, p. 255). Neste sentido, não parece demais entender que a demanda pela possibilidade de doar sangue esteja relacionada simultaneamente às esferas de reconhecimento do direito e da solidariedade, conforme se buscará demonstrar.

Honneth tem uma visão bastante alargada da segunda esfera de reconhecimento, o direito, entendendo que uma pluralidade de demandas distintas poderia, em última análise, ser entendida como argumentos morais em torno do princípio da igualdade jurídica (2003b, p. 170). Por outro lado, o teórico parece relacionar a terceira esfera de reconhecimento, a solidariedade, quase que exclusivamente com o sucesso profissional dentro de uma estrutura capitalista de divisão do trabalho baseada na meritocracia (HONNETH, 2003b, pp. 140-141 e 147-148), de maneira que a mesma pouco poderia contribuir para o presente debate.

Parece plausível, portanto, agrupar a demanda como uma luta moral por reconhecimento na esfera do direito, inclusive por se manifestar na busca por igual tratamento jurídico, dentro da lógica de que o status de uma pessoa de direito historicamente representou o fundamento para a extensão de direitos pré-existentes a novos grupos sociais. Neste sentido, a eliminação da proibição de doação de sangue albergaria homens gays no ordenamento jurídico em posição de igualdade, contribuindo para a sua autorrelação prática no campo do respeito.

É possível, todavia, entender que a esfera da solidariedade se relaciona de maneira mais geral com padrões de hierarquia social que valorizam o indivíduo na medida de sua contribuição

\footnotetext{
143 "Social injustice is experienced the moment it can no longer be rationally understood why an institutional rule should count on agreement in accordance with generally accepted reasons".
} 
para com a reprodução social (HONNETH, 2003c, p. 263) ${ }^{144}$. Neste sentido, é possível argumentar que a vedação à doação de sangue estabelece parâmetros assimétricos de valoração da contribuição social das vivências homossexual e heterossexual, a partir de concepções estigmatizantes daquela. Significa dizer, a capacidade de contribuir para a vida comum por meio da doação de sangue é vedada aos sujeitos em razão de um determinado "estilo de vida", alijando-os, neste sentido, de estima social. Segundo Honneth, "as relações de estima social estão sujeitas a uma luta permanente na qual os diversos grupos procuram elevar [...] o valor das capacidades associadas à sua forma de vida" (2003a, p. 207). A demanda pelo fim da vedação de doação de sangue aos HSHs busca, assim, novos padrões sociais de reconhecimento das capacidades de homens gays contribuírem com a coletividade em detrimento de padrões assimétricos que os desvalorizam como "perigosos" ou "promíscuos"145. Com efeito, a vedação não apenas exerce um efeito negativo sobre a autoestima de homens gays, mas termina por legitimar outros tipos de discriminação que sofrem (LARKIN, 2011).

É possível argumentar, portanto, que a manutenção da vedação à doação de sangue por HSHs, dentro do esquema proposto por Honneth, apresenta um desrespeito ao reconhecimento de homens gays tanto na esfera do autorrespeito, a partir da privação de direitos que lhes nega o status de um parceiro de interação social de igual valor, quanto na esfera da autoestima, ao qualificar de maneira inferior e degradante à sua vivência ${ }^{146147}$.

\footnotetext{
${ }^{144}$ No mesmo sentido, "para Honneth, a dignidade e o status social de uma pessoa correspondem ao grau de aceitação social do seu método de autorrealização no contexto do horizonte cultural de tradições de uma dada sociedade" (FERES JÚNIOR \& POGREBINSCHI, 2010, p. 127).

${ }^{145}$ Neste sentido, "o terceiro tipo de reconhecimento é alcançado por meio do sentimento de solidariedade social advindo da aprovação coletiva de estilos de vida particulares [...]. A positividade moral de tal reconhecimento reside no alargamento das possibilidades de realização dos diferentes modos de vida em sociedade, que, por seu turno, contribui para destradicionalizar os valores sociais". (FERES JÚNIOR \& POGREBINSCHI, 2010, pp. 128 129).

146 “A degradação valorativa de determinados padrões de autorrealização tem para seus portadores a consequência de eles não poderem se referir à condução de sua vida como a algo a que caberia um significado positivo no interior de uma coletividade; por isso, para o indivíduo, vai de par com a experiência de uma tal desvalorização social, de maneira típica, uma perda de autoestima pessoal, ou seja, uma perda de possibilidade de se entender a si próprio como um ser estimado por suas propriedades e capacidades características". (HONNETH, 2003a, pp. 217-218).

${ }^{147}$ Com efeito, as esferas do Direito e da Solidariedade, e as demandas por reconhecimento em cada uma delas, muitas vezes apresentam uma interpenetração. Nesse sentido, "por vezes demandas por reconhecimento formuladas na esfera da Solidariedade podem ser deslocadas para a segunda esfera do reconhecimento - o Direito - com o recurso ao princípio da igualdade jurídica. Isto porque, como visto, a fragmentação do respeito em reconhecimento jurídico e estima social passou a exigir uma distinção entre capacidades universalizáveis e capacidades individuais que, contudo, não é estanque. Assim, na medida em que determinadas capacidades individuais cujo reconhecimento específico é buscado na terceira esfera do reconhecimento passam a ser reconduzidas ao conceito de autonomia individual e às suas condições, torna-se possível que uma determinada demanda seja formulada em termos de direito e não de valorização social” (CORBO, 2015, p. 65).
} 
Podemos concluir assim que, em que pese as diferenças fundamentais entre os aportes teóricos desenvolvidos por ambos os autores, que direcionam seus holofotes para facetas diferentes da questão ora sub exame, ambas podem ser utilizadas de forma rica para se concluir que a vedação à doação de sangue por HSHs gera uma injustiça e um desrespeito aos homens gays no campo do reconhecimento.

\section{PERSPECTIVAS JURÍDICAS}

Muitos autores, gestores e ativistas defendem uma revisão da vedação da doação de sangue por homens homossexuais, como forma de simultaneamente garantir um maior suprimento de sangue e tutelar a dignidade deste grupo. Advoga-se, então, que as políticas de doação de sangue devem se concentrar em comportamentos de risco, independentemente de por quem adotados, e que não há qualquer motivo para vedar a doação de sangue de um homem homossexual que faça sexo protegido em uma relação estável.

Neste sentido, a proibição de doação de sangue por HSHs é objeto de crescente oposição por parte da academia médica, a partir da noção de que a mesma representa uma visão ultrapassada da AIDS e não se sustenta mais diante dos avanços das técnicas de testagem. Não é, entretanto, somente neste campo que a mesma vem sendo questionada, e os profissionais do Direito têm cada vez mais a colocado em xeque, com base no discurso e na gramática que lhes são próprios.

Alguns destes argumentos jurídicos desenvolvidos para a sua contestação refletem em certa medida os problemas que a norma traz para o reconhecimento de homens gays, conforme visto anteriormente. Neste sentido, dentro de uma discursividade constitucional baseada na ideia de direitos fundamentais, defende-se que a vedação viola a dignidade humana destes sujeitos, além de violar os princípios da igualdade e da proporcionalidade. Embora dados os limites do presente artigo o exaurimento do tema na seara jurídica não seja possível, cabe fazer algumas considerações sobre as possibilidades do uso do Direito para o enfrentamento dos problemas de reconhecimento representados pela vedação.

Discute-se academicamente se o reconhecimento no campo constitucional deriva do Princípio da Dignidade da Pessoa Humana (SARMENTO, 2016) ou do Princípio da Igualdade (BARROSO \& OSÓRIO, 2014). Independentemente do seu fundamento normativo, fato é que 
a dimensão do reconhecimento dos sujeitos detém hierarquia constitucional enquanto direito fundamental, devendo as políticas públicas estatais observá-lo. Assim, Sarmento:

\begin{abstract}
É possível falar em um direito fundamental ao reconhecimento, que é um direito ao igual respeito da identidade pessoal. Trata-se de um direito que tem uma faceta negativa como outra positiva. Em sua faceta negativa, ele veda as práticas que desrespeitam as pessoas em sua identidade, estigmatizando-as. Na dimensão positivam ele impõe ao Estado a adoção de medidas voltadas ao combate dessas práticas e à superação dos estigmas existentes (2016, pp. 256-257).
\end{abstract}

Parece claro, portanto, que a vedação à doação de sangue por HSHs não sobrevive ao escrutínio com o direito fundamental ao reconhecimento em sua faceta negativa, na medida em que perpetua estereótipos negativos e estigmatizantes em relação aos homens homossexuais, conforme explorado na seção anterior.

Neste sentido, a restrição se choca com o mister constitucional de promoção de uma sociedade mais tolerante e igualitária que exorta os poderes públicos a adotar medidas de enfrentamento a padrões culturais discriminatórios e estigmatizantes. A alteração da norma, para retirar a proibição da doação por HSHs, igualando-os aos casais de sexo diferente, com base na ideia de "comportamentos de risco" transmitiria uma poderosa imagem simbólica de igualdade, ajudando a combate uma cultura que vê os homossexuais como menos valiosos e perigosos. Neste sentido, Lopes defende que:

O direito - os ordenamentos jurídicos - ajuda a naturalizar as diferenças e as desigualdades comuns na cultura. A mudança no direito não apenas se segue às mudanças culturais, mas ajuda a promovê-las. Logo, o direito pode promover mudanças e remover injustiças historicamente consolidadas, requerendo para isso que algumas instituições jurídicas sejam mobilizadas (2005, p. 73).

Por sua vez as violações ao Princípio da Igualdade e à Proporcionalidade decorreriam, de um lado, do fato de que a restrição se baseia na própria orientação sexual do sujeito, e não em seu comportamento concreto e individualizado, sendo, portanto, discriminatória na medida em que impõe um tratamento diferente injustificado entre homossexuais e heterossexuais (LARKIN, 2011), e do outro, do fato de que a norma fere o segundo subprincípio da proporcionalidade $-\mathrm{o}$ da necessidade -148 uma vez que existe outra medida igualmente eficiente

\footnotetext{
148 Grosso modo, a proporcionalidade é uma técnica de avaliação de medidas que importem em colisão de princípios, como por exemplo normas que restrinjam direitos fundamentais, que se subdivide em três subprincípios, cada um representando um teste sucessivo de aferição da legitimidade desta medida: (a) adequação, que envolve a avaliação se a medida, em algum nível mínimo, contribui para a consecução do fim a que se destina; (b) necessidade, em que se verifica a existência de outras medidas que poderiam promover o mesmo fim com a mesma intensidade, mas de forma menos lesiva aos interesses ou direitos contrapostos; e (c) proporcionalidade stricto sensu, em que se realiza o sopesamento entre o nível de promoção do fim e o nível de restrição aos interesses e direitos atingidos.
} 
para garantir a qualidade do sangue, qual seja, estabelecer uma política baseada na ideia de comportamentos de risco, que é menos lesiva ao direito contrapostos de homens gays (e ao interesse estatal de permitir ao maior número de pessoas doar sangue $)^{149}$.

Em sentido oposto, em que pese a crescente rejeição à vedação da doação de sangue por homossexuais no meio científico, esta questão está longe de ser pacífica. Opositores da medida apontam que, diante das limitações de ordem técnica e operacional para a testagem do sangue, principalmente durante o período da "janela imunológica", em que a detecção do vírus do HIV não é possível, bem como a prevalência estatística da AIDS entre HSHs, o risco de infecção do receptor legitimaria a restrição (TANAKA \& OLIVEIRA, 2010; SANTIS, GUEDES \& UBIALI, 2016). Estas colocações, por outro lado, não ajudam a esclarecer o que justificaria a vedação à doação de sangue por parte de um homossexual que não praticou qualquer comportamento de risco, não infirmando, portanto, o argumento construído no presente artigo.

Com base nestes pressupostos, algumas estratégias de contestação à proibição têm sido colocadas no cenário jurídico nacional, com destaque para duas iniciativas: (a) a Recomendação Conjunta DPU GT LGBTI/DPE $n^{\circ} 01 / 2016$ e (b) a ADI $n^{\circ} 5.543^{150}$.

A supracitada Recomendação foi formulada conjuntamente pelas Defensorias Públicas da União e do Estado da Bahia e expedida em 15.02.2016, para exortar o Ministério da Saúde a revogar a vedação temporária de doação por HSHs. Embora a medida não tivesse por objeto a Portaria $n^{\circ} 158 / 2016$, e sim a Portaria $n^{\circ} 2.712 / 2013$, que foi revogada pela atual, a regra acerca da exclusão de HSHs permaneceu a mesma em ambos os diplomas normativos. Segundo a recomendação, a vedação viola a Constituição por ser discriminatória e despida de razoabilidade, na medida em que "o simples fato de haver relações sexuais entre homens não legitima qualquer restrição, uma vez que não há aqui qualquer indicativo de exposição a fatores de riscos, como multiplicidade de parceiros, realização de atividade sexual sem proteção ou contato com doenças transmitidas sexualmente" ${ }^{151}$.

Já ADI n 5.543 foi ajuizada pelo Partido Socialista Brasileiro em 07.06.2016, visando à declaração de inconstitucionalidade, com pedido liminar, do dispositivo que previa a exclusão

\footnotetext{
${ }^{149}$ No mesmo sentido: AVILA, 2016, pp. 58-60.

${ }^{150}$ Deve-se destacar, por outro lado, que as mesmas foram selecionadas em razão de sua atualidade, e não por terem sido os únicos questionamentos jurídicos ou judiciais da vedação. Neste sentido, por exemplo, o Ministério Público Federal no Piauí propôs a ACP 2006.40.00.001761-6. Embora num primeiro momento a liminar tenha sido deferida pela $1^{\mathrm{a}}$ instância, a decisão acabou cassada na $2^{\mathrm{a}}$ instância.

151 "DPU recomenda a ministério que permita doação de sangue por homossexuais" http://www.dpu.gov.br/noticias-bahia/136-noticias-ba-slideshow/29521-dpu-recomenda-ao-ms-acabardiscriminacao-na-doacao-de-sangue-de-homossexuais
} 
temporária de HSHs. A inicial dá destaque ao fato de que homens homossexuais que possuam o mínimo de atividade sexual ficam, na prática, permanentemente excluídos da doação de sangue. Neste sentido, defende ser a norma preconceituosa e discriminatória em razão da orientação sexual, importando em lesão à dignidade dos envolvidos e impedindo-os de exercer a solidariedade humana por meio da doação de sangue. Aduz, ainda, que a legislação brasileira é marcada por visões ultrapassadas que colocam homossexuais como grupo de risco exclusivamente pela orientação sexual, sem considerar-se o efetivo comportamento individual. Embora não faça menção expressa à ideia de reconhecimento, a exordial destaca, o caráter estigmatizante da norma, nos termos abordados na seção anterior:

94. A Portaria n. 158/2016-MS e a RDC n. 34/2014-ANVISA são eivadas de alto grau de preconceito e estigmatizam pessoas. Note-se que estigmatizar pessoas, ao invés de avaliar comportamentos, não apenas compromete a dignidade daqueles que foram alvos do preconceito, como ainda demonstram ser falhos no alcance da segurança. Essa é a diferença entre agir com segurança e agir com preconceito.

95. No intuito de demonstrar o que fora explicitado, pergunta-se: há alguma conduta praticada exclusivamente por homens homossexuais hábil a justificar a previsão normativa que ora se impugna? A conduta que justifica tal previsão não seria praticada também por casais heterossexuais?

96. Além de ato solidário por excelência, doar sangue é atitude intimamente ligada com o exercício da cidadania. Por meio da doação, o indivíduo contribui com a saúde coletiva, honrando assim os valores republicanos que fundam o Estado brasileiro.

97. Ao tolher do homossexual esse direito, embaraça-se, por consequência, larga parcela de sua cidadania, ferindo seu direito de ajudar a coletividade, de ser útil à vida de pessoa necessitada, de prestar auxílio a quem precisa, de ter atitude fraterna.

[...]

108. É de se ressaltar que a presunção absoluta de que todo homem homossexual deve ser incluído como "grupo de risco" fere de morte sentimentos mais intrínsecos do ser humano, colocando em cheque a igual consideração e respeito com que todos merecem ser tratados pelo Estado.

109. Sob o pretexto de privilegiar a segurança no controle de saúde do sangue, o Estado brasileiro admite que determinado grupo de pessoas, por mera questão ontológica - e não em razão de comportamentos adotados -, seja barrado dos hemocentros e taxado de "impuro", de "aidético", frente às pessoas supostamente "normais" e possuidoras de sangue hipoteticamente "saudável". A estigmatização é flagrante e absurda!

110. Nesse sentido, o elevado grau da ofensa constitucional justifica a retirada dos dispositivos em exame do ordenamento jurídico brasileiro, fazendo prevalecer os direitos fundamentais à igualdade, à não discriminação e à dignidade da pessoa humana. (grifos no original)

Em 08.06.2016, o Ministro-Relator Edson Fachin determinou a adoção do rito abreviado para o julgamento de ações diretas de inconstitucionalidade previsto no art. 12 da Lei $\mathrm{n}^{\circ}$ 9.868/99152, em decisão que indicou a sua tendência em julgar procedente o pedido ao afirmar que:

152 Art. 12. Havendo pedido de medida cautelar, o relator, em face da relevância da matéria e de seu especial significado para a ordem social e a segurança jurídica, poderá, após a prestação das informações, no prazo de dez 
aqui se está diante de regulamentação que toca direto ao núcleo mais íntimo do que se pode considerar a dignidade da pessoa humana, fundamento maior de nossa República e do Estado Constitucional que ela vivifica.

Não me afigura correto ou salutar que se coadune com um modo de agir que evidencie constante apequenar desse princípio maior, tolhendo parcela da população de sua intrínseca humanidade ao negar-lhe a possibilidade de exercício de empatia e da alteridade como elementos constitutivos da própria personalidade.

Sob qualquer ângulo que se olhe para a questão, o correr do tempo mostra-se como um inexorável inimigo. Quer para quem luta por vivificar e vivenciar a promessa constitucional da igualdade, quer por quem luta viver e tanto precisa do olhar solidário do outro.

Muito sangue tem sido derramado em nosso país em nome de preconceitos que não se sustentam, a impor a célere e definitiva análise da questão por esta Suprema Corte $^{153}$.

No mesmo sentido, em 06.09.2016, a Procuradoria-Geral da República se manifestou pelo deferimento da medida cautelar na ADI, dando destaque para os efeitos estigmatizantes decorrentes da adoção de um modelo com base na ideia de "grupos de risco" e não de "comportamentos de risco":

Na prática, essa sistemática acaba por classificar gays e bissexuais como grupo de risco (conceito abandonado, conforme exposto). Presume-se que essas pessoas estariam sempre em situação de risco acrescida ou em comportamento de risco. Todavia, o critério justificável na atualidade leva em conta práticas sexuais concretas, não a identidade ou a orientação sexual das pessoas envolvidas.

Para justificar a proibição de doação de sangue por homens que fazem sexo com outros homens, argumenta-se que a prática de sexo anal traria maiores riscos de transmissão de doenças do que o sexo vaginal. De fato, o risco de transmissão do HIV e de outras doenças venéreas é maior no sexo anal, por maior aptidão da região a pequenos sangramentos e, desse modo, ao contato com sangue contaminado. Contudo, é notório que essa prática sexual não é prerrogativa masculina. Pode fazer parte de relações homo ou heteroafetivas. Risco em relações sexuais desprotegidas existe independentemente da orientação sexual ou gênero dos indivíduos envolvidos. Estudos demonstram, aliás, que parcela substancial de heterossexuais mantêm relações sexuais anais e tendem a usar preservativos com menor regularidade, exatamente por não haver risco de concepção indesejada.

Por outro lado, possibilidade de contaminação por doenças restará afastada se a prática sexual ocorrer com uso de preservativos. Logo, simples exclusão de candidatos a doação de sangue (hétero ou homossexuais) que, em determinado lapso, hajam praticado relações sexuais desprotegidas (anais ou vaginais), bastaria para alcançar os objetivos pretendidos pelas normas, sem necessidade de impor discriminação pautada em orientação sexual, como fizeram as normas sob exame.

$[\ldots]$

Ao fim e ao cabo, as normas promovem tratamento discriminatório entre homens com fundamento único em sua orientação sexual. Vão em sentido oposto ao esforço estatal para coibir violência contra homossexuais. Dados do Relatório sobre Violência Homofóbica no Brasil

$[\ldots]$

dias, e a manifestação do Advogado-Geral da União e do Procurador-Geral da República, sucessivamente, no prazo de cinco dias, submeter o processo diretamente ao Tribunal, que terá a faculdade de julgar definitivamente a ação.

${ }^{153}$ Disponível em: http://www.stf.jus.br/portal/processo/verProcessoPeca.asp?id=309695587\&tipoApp=. pdf 


\begin{abstract}
Não se pretendem suprimir, com esta ação direta, em absoluto, as imprescindíveis cautelas que envolvem a doação de sangue, voltadas a assegurar a higidez do sistema de hemoterapia, livre de contaminação por vírus HIV e outros. Contudo, as normas criam rótulos que deslocam o foco do risco apresentado por determinados comportamentos e práticas, para noções estereotipadas sobre estilos de vida e orientação sexual, o que termina por estigmatizar grupos já alvo de preconceito e violência (homens gays e bissexuais) e imunizar outros (homens heterossexuais e mulheres) $[\ldots]^{154}$
\end{abstract}

Cabe destacar, por fim, que a revogação da vedação de doação de sangue por meio de sua declaração de inconstitucionalidade judicial tem interessante precedente no direito comparado: a Corte Constitucional colombiana, reconhecida como uma das mais progressistas e criativas do mundo, o fez na decisão T-248/2012 155 . Naquele país, as normas aplicáveis previam a exclusão por 15 anos de HSHs diante do "risco potencial" de infecção; a Corte entendeu que a regra retratava um estágio ultrapassado do desenvolvimento científico em torno da AIDS, determinando a adoção de um paradigma baseado na ideia de comportamentos de risco.

\title{
6 CONSIDERAÇÕES FINAIS
}

As normas do Ministério da Saúde proíbem a doação de sangue por homens que tenham se relacionado sexualmente com outros homens nos últimos doze meses, o que gera uma exclusão de facto da possibilidade de homens gays contribuírem com os estoques de sangue no Brasil. A política de restrições à doação de sangue por HSHs foi adotada mundialmente como uma resposta à crise da AIDS, que atingiu especialmente a comunidade homossexual masculina. Embora pudesse ter parecido razoável em outro contexto histórico, a mesma vem sofrendo muitos questionamentos por parte da comunidade científica, que alega que a mesma não mais se sustenta diante do desenvolvimento científico, e de juristas e ativistas, que destacam os efeitos deletérios que a mesma gera para os direitos e a identidade de homens homossexuais.

Com efeito, conforme analisado, a restrição se baseia em concepções científicas ultrapassadas que acabam por reforçar estereótipos negativos que relacionam homossexualidade a "promiscuidade" e "perigo", atuando na perpetuação de estigmas. Assim, de acordo com as chaves teóricas formuladas por Nancy Fraser, a política viola à paridade de

\footnotetext{
${ }^{154}$ Disponível em: http://www.stf.jus.br/portal/processo/verProcessoPeca.asp?id=310258225\&tipoApp=. pdf.

${ }^{155}$ Disponível em: http://www.corteconstitucional.gov.co/relatoria/2012/t-248-12.htm
} 
participação de homens homossexuais em sua condição intersubjetiva, estabelecendo regras institucionais que lhes conferem um status social subordinado. A reversão desta proibição atuaria como remédio de reconhecimento afirmativo, mas com potencial transformativo a longo tempo, dada a importância e significados atrelados à doação de sangue, caracterizando-se como uma "reforma não-reformista".

Por outro lado, com base na teoria desenvolvida por Axel Honneth, a proibição analisada no presente artigo pode ser entendida como um desrespeito ao reconhecimento de homens gays tanto na esfera do direito, quanto na esfera da solidariedade. Em primeiro lugar, na esfera do direito, a regra importa em um tratamento jurídico desigual, gerando um impacto negativo na autorrelação prática de homens homossexuais no campo do respeito. Em segundo lugar, na esfera do reconhecimento, a proibição impede a contribuição social destes sujeitos em razão de considerações estigmatizantes quanto ao seu "estilo de vida", reforçando padrões assimétricos de valorização social, que importam na violação da sua autoestima.

Neste sentido, é possível concluir que a restrição à doação de sangue representa uma violação ao direito de reconhecimento de homens homossexuais, nos termos das teorias formuladas por ambos os autores. Cabe destacar, por fim, que mesma foi recentemente questionada junto ao Supremo Tribunal Federal, que, caso declare a sua inconstitucionalidade, atuará na garantia do direito ao reconhecimento dos homossexuais masculinos.

\section{REFERÊNCIAS}

ASSY, Bethânia; FERES JUNIOR, João. "Reconhecimento". In: BARRETO, Vicente de Paulo (coord.). Dicionário de Filosofia do Direito. São Leopoldo, Unisinos, 2009, pp. 705-710.

AVILA, Juliana Carreiro. Vedação de doações de sangue de homens homossexuais: uma análise à luz da Constituição de 1988. (Trabalho de conclusão de curso). Graduação em Direito. Universidade do Estado do Rio de Janeiro, Rio de Janeiro, 2016, 86p.

BARROSO, Luís Roberto; OSÓRIO, Aline Rezende Peres. "Sabe com quem está falando?": Algumas notas sobre o princípio da igualdade no Brasil contemporâneo. 2014, 24p. Disponível em: http://www.luisrobertobarroso.com.br/wpcontent/themes/LRB/pdf/SELA_Yale_palestra_igualdade_versao_fina.pdf

CORBO, Wallace de Almeida. Por que não uma igualdade "para valer"?: reconhecimento, minorias e a vedação à discriminação indireta no brasil. (Dissertação de Mestrado). Programa 
de Pós-Graduação em Direito. Universidade do Estado do Rio de Janeiro, Rio de Janeiro, 2015, $254 \mathrm{p}$.

ERIBON, Didier. Reflexões sobre a questão gay. Rio de Janeiro: Companhia de Freud, 2008, $455 \mathrm{p}$.

FACCHINI, Regina; FRANÇA, Isadora Lins. "De cores e matizes: sujeitos, conexões e desafios no Movimento LGBT brasileiro". Sexualidad, Salud y Sociedad. Revista Latinoamericana. N. 3, 2009, pp. 54-81.

FERES JÚNIOR, João; POGREBINSCHI, Thamy. "Reconhecimento". In: FERES JÚNIOR, João; POGREBINSCHI. Teoria Política Contemporânea: uma introdução. Rio de Janeiro: Elsevier, 2010, pp. 113-136.

FRASER, Nancy. "Social Justice in the Age of Identity Politics: Redistribution, Recognition, and Participation". In: FRASER, Nancy; HONNETH, Axel. Redistribution or Recognition?: a political-philosophical exchange. Londres: Verso, 2003a. pp. 7-109.

FRASER, Nancy "Distorted Beyond All Recognition: A rejoinder to Axel Honneth". FRASER, Nancy; HONNETH, Axel. Redistribution or Recognition?: a political-philosophical exchange. Londres: Verso, 2003b, pp. 198-236.

FRASER, Nancy. "Repensando a questão do reconhecimento: superar a substituição e a reificação na política cultural”. In: BALDI, César Augusto. (org.). Direitos Humanos na Sociedade Cosmopolita. Rio de Janeiro: Renovar, 2004, pp. 601-621.

FRASER, Nancy. "Redistribuição, Reconhecimento e Participação: por uma Concepção Integrada de Justiça". In: SARMENTO, Daniel; IKAWA, Daniela; PIOVESAN, Flávia. (coords.). Igualdade, Diferença e Direitos Humanos. Rio de Janeiro: Lumen Juris, 2010, pp. 167-190.

FRASER, Nancy; HONNETH, Axel. Redistribution or Recognition?: a politicalphilosophical exchange. Londres: Verso, 2003, 276p.

GOFFMAN, Erving. Estigma: Notas sobre a manipulação da identidade deteriorada. $4^{\mathrm{a}}$ Ed. Rio de Janeiro, LTC, 1988, 158p. 
GOLDBERG, Naomi G.; GATES, Gary J. "Effects of lifting the blood donation ban on men who have sex with men". In: Pittsburgh Journal of Environmental and Public Health Law, vol. 5, 2011, pp. 49-59.

HONNETH, Axel. Luta por Reconhecimento: A gramática moral dos conflitos sociais. São Paulo: Ed. 34, 2003a, 296p.

HONNETH, Axel. "Redistribution as Recognition: A Response to Nancy Fraser". FRASER, Nancy; HONNETH, Axel. Redistribution or Recognition?: a political-philosophical exchange. Londres: Verso, 2003b, pp. 110-197.

HONNETH, Axel. "The Point of Recognition: A Rejoinder to the Rejoinder" FRASER, Nancy; HONNETH, Axel. Redistribution or Recognition?: a political-philosophical exchange. Londres: Verso, 2003c, pp. 237-267

LARKIN, Whitney. "Discriminatory Policy: Denying Gay Men the Opportunity to Donate Blood”. In: Houston Journal of Health Law \& Policy, vol 11, 2011, pp. 121-148.

LOPES, José Reinaldo de Lima. "O direito ao reconhecimento para gays e lésbicas". In: Sur Revista Internacional de Direitos Humanos, ano 2, Número 2, 2005, pp. 64-95.

MCADAM, Christopher; PARKER, Logan. "An antiquated perspective: lifetime ban for MSM blood donations no longer global norm”. In: DePaul Journal of Health Care Law, Vol. 16.1, 2014, pp. 21- 65 .

MORRISON, Mathew L. "Bad Blood: an examination of the constitutional deficiencies of the FDA's 'gay blood ban’”. In: Minnesota Law Review, Vol. 99, 2015, pp. 2363-2404.

PELÚCIO, Larissa; MISKOLCI, Richard. "A prevenção do desvio: o dispositivo da aids e a repatologização das sexualidades dissidentes". In: Sexualidad, Salud y Sociedad. Revista Latinoamericana. N. 1, 2009, pp. 125-157.

TANAKA, Mirtha Susana Yamada; OLIVEIRA, Aline Albuquerque de. "Homens que fazem sexo com homens e análise ética da triagem dos doadores de sangue no Brasil". In: Revista Bioética, 2010, 18(3), pp. 589-601.

TREVISAN, João Silvério. Devassos no Paraíso: a homossexualidade no Brasil, da colônia à atualidade. $8^{\mathrm{a}}$ Ed. Revisada e Ampliada. Rio de Janeiro: Record, 2011, 588p. 
SANTIS, Gil Cunha de; GUEDES, Maria Cleusa; UBIALI, Eugênia Maria Amorim. "Prazo que restringe doação de sangue por homossexual homem é razoável". In: Consultor Jurídico, opinião, publicado em 28.06.2016. Disponível: http://www.conjur.com.br/2016-jun-28/prazorestringe-doacao-sangue-homossexual-homem-razoavel.

SANTOS, Gustavo Gomes da Costa. "Mobilizações homossexuais e Estado no Brasil: São Paulo (1978-2004). In: Revista Brasileira de Ciências Sociais. Vol. 22 nº 63, 2007, pp. 121 173.

SARMENTO, Daniel. "Reconhecimento". In: SARMENTO, Daniel. Dignidade da Pessoa Humana: conteúdo, trajetórias e metodologia. Belo Horizonte: Fórum, 2016, pp. 241-298.

SIMÕES, Júlio Assis; FACCHINI, Regina. Na Trilha do Arco-Íris: do movimento homossexual ao LGBT. São Paulo: Fundação Perseu Abramo, 2009, 196p.

STERN, Mark Joseph. "There's an Urgent Need for Blood Donors in Orlando. Most Gay Men Still Can't Donate”. In: Slate. Outward. Publicado em 12.06.2016. Disponível em: http://www.slate.com/blogs/outward/2016/06/12/orlando_pulse_gay_nightclub_shooting_gay _men_can_t_donate_blood.html.

\title{
THE GAY BLOOD DONATION BAN: AN ANALYSIS UNDER THE THEORIES OF RECOGNITION OF FRASER AND HONNETH
}

\begin{abstract}
The aim of the present paper is to analyze the gay blood donation ban from the perspective of Nancy Fraser's and Axel Honneth's theories of recognition. First, the Brazilian legal framework on the subject will be exposed, establishing its historical origins as response to the AIDS epidemic. The distinctive policies adopted worldwide on the subject of the possibility of blood donation by gay men will be discussed, in order to determine which one is more in line with the present stage of scientific development on the subject of AIDS and hemotherapy. On the second part, the theories of Fraser and Honneth will be examined, discussing key concepts developed by each author and the main differences between their ideas. On the following section, the gay blood ban will be analyzed considering the theoretical tools developed previously, in order to conclude that it represents a violation of the recognition of gay men. Finally, the legal strategies underway in Brazil to question the ban will be briefly summarized.
\end{abstract}

Keywords: Blood donation. Homosexuality. Theory of recognition. 